Państwo-Prawo-Administracja

$1(1) / 2016$

ISSN 2451-1676

DOI: http://dx.doi.org/10.21784/PPA.2016.003

JACEK WOJCIECHOWSKI

Uniwersytet Mikołaja Kopernika w Toruniu

\title{
Prawnokarne regulacje dotyczące zakazu podawania do wiadomości publicznej wyników sondaży w okresie ciszy referendalnej
}

Criminal law measures pertaining to the prohibition against disclosure of the results of opinion polls during the referendum silence

\section{Streszczenie:}

W niniejszym opracowaniu dokonana została analiza czynów zabronionych dotyczących zakazu podawania do wiadomości publicznej wyników sondaży w czasie trwania ciszy referendalnej. Cisza referendalna, podobnie jak cisza wyborcza wywołuje wiele kontrowersji, a prawnokarne regulacje dotyczące zakazu podawania do wiadomości publicznej wyników sondaży są jednym z jej istotnych i nieodłącznych elementów. W artykule poruszone zostały zagadnienia dotyczące przedmiotu ochrony, strony przedmiotowej, podmiotu i strony podmiotowej wskazanych występków. Poza analizą normatywnej 
konstrukcji tych przestępstw autor przybliża również genezę wskazanych regulacji karnych oraz charakteryzuje ich główne wady.

\begin{abstract}
:
This paper analyses the prohibited acts entailing the public disclosure of the opinion poll results during the referendum silence. Similarly as in the case of electoral silence, the referendum silence provokes considerable controversy, whereas criminal law measures applicable to the prohibition against disclosure of the results of opinion polls constitute its fundamental and inherent elements. The paper addresses the issues pertaining to the object of protection, the conduct and circumstances of the offence, the perpetrator and the perpetrator's intent in the acts of forbidden disclosure. In addition to the analysis of the normative structure of the described offences, the author provides an insight into the origins of the referred criminal laws and outlines their main drawbacks.
\end{abstract}

Słowa kluczowe: cisza referendalna; zakaz podawania wyników sondaży w czasie ciszy referendalnej; referendum.

Keywords: the period of silence referendum, the offence of publicising the results of election polls during the period of the silence referendum.

\title{
1. Wprowadzenie
}

W realiach ustrojowych III Rzeczpospolitej referendum należy do głównych instrumentów bezpośredniego sprawowania władzy publicznej. Normatywny kształt tej instytucji podobnie, jak ma to miejsce przy konstrukcji wyborów opiera się na wykorzystaniu aktu głosowania, w trakcie którego obywatele decydują o najważniejszych sprawach państwa lub wspólnoty samorządowej. W celu zapewnienia należytej ochrony procesu referendalnego oraz zapadających w jego ramach rozstrzygnięć ustawodawca zdecydował się wzorem rozwiązań obowiązujących na gruncie prawa wyborczego ${ }^{1}$ ustanowić specy-

Zob. Ustawa z dnia 5 stycznia 2011 r. Kodeks wyborczy (Dz.U. z 2011 r., nr 21, poz. 112 ze zm.) - dalej jako K. wyb. Zob. Art. 500 „Kto, w związku z wyborami w okresie od zakończenia kampanii wyborczej aż do zakończenia głosowania, 
ficzny reżim prawny określany mianem ciszy referendalnej, w czasie którego zabronione jest m.in. podawanie do wiadomości publicznej wyników badań opinii publicznej (sondaży). Realizację tak ustanowionych zakazów ma gwarantować art. 85 ustawy o referendum ogólnokrajowym ${ }^{2}$ oraz art. 70 ustawy o referendum lokalnym ${ }^{3}$, w których stypizowane zostały występki podawania do wiadomości publicznej wyników sondaży w czasie od zakończenia kampanii referendalnej do zakończenia głosowania w referendum. Uwagę zwraca fakt, że pierwsze tego rodzaju czyny zabronione pojawiły się w polskim porządku prawnym dopiero na przełomie XX/XXI wieku'4 a ich wprowadzenie związane było m.in. zainicjowaną w 1989 roku demokratyzacją ustroju państwowego ${ }^{5}$ oraz błyskawicznym rozwojem

podaje do publicznej wiadomości wyniki przedwyborczych badań (sondaży) opinii publicznej dotyczących przewidywanych zachowań wyborczych lub przewidywanych wyników wyborów, lub wyniki sondaży wyborczych przeprowadzanych w dniu głosowania podlega grzywnie od 500000 do 1000000 złotych".

2 Ustawa z dnia 14 marca 2003 roku o referendum ogólnokrajowym (Dz.U. z 2003 r., nr 57, poz. 507 ze zm.) -dalej jako URef.Ogól.

3 Ustawa z dnia 15 września 2000 roku o referendum lokalnym (Dz.U. z 2000 r., nr 88, poz. 985 ze zm.) - dalej jako URef.Lok.

4 Zob. art. 43a ust. 1 Ustawy z dnia 29 czerwca 1995 roku o referendum ogólnokrajowym (Dz.U. z 1995 r., nr 99, poz. 487 ze zm.) wprowadzony przez ustawę o zmianie ustawy o wyborze Prezydenta Rzeczypospolitej Polskiej oraz niektórych innych ustaw z dnia 28 kwietnia 2000 roku (Dz.U. z 2000 r., nr 43, poz. 488.). Zgodnie z treścią tego przepisu: „Na 24 godziny przed dniem głosowania zabrania się podawania do publicznej wiadomości wyników przedreferendalnych badań (sondaży) opinii publicznej, dotyczących przewidywanych zachowań głosujących i wyniku referendum, a także sondaży przeprowadzanych w dniu głosowania. 2 . Kto $\mathrm{z}$ naruszeniem zakazu, o którym mowa w ust. 1, podaje do wiadomości publicznej wyniki przedreferendalnych badań (sondaży) opinii publicznej dotyczących przewidywanych zachowań głosujących i wyniku referendum, a także sondaży przeprowadzanych w dniu głosowania, podlega grzywnie od 500000 do 1000000 złotych.". W przypadku referendum lokalnego przestępstwo podawania do wiadomości publicznej wyników sondaży wprowadzone zostało przez ustawę o referendum lokalnym z dnia 15 września 2000 roku (Dz.U. z 2000 r., nr 88, poz. 985 ze zm.).

5 Tak w odniesieniu do wyborów: J. Raciborski, Polskie wybory. Zachowania wyborcze społeczeństwa polskiego w latach 1989-1995, Warszawa 1997, s. 31. Jak wskazuje Autor: „Już pierwsza kampania wyborcza mająca miejsce w wyborach parlamentarnych w 1989 roku okazała się zaskakująco intensywna i zróżnicowana pod 
środków masowego przekazu, które zaczęły brać czynny udział $\mathrm{w}$ procesie wyborczym oraz referendalnym 6 .

Należy w tym miejscu zauważyć, że znamiona obu czynów zabronionych zostały skonstruowane w sposób zbliżony do normatywnej konstrukcji występku określonego w art. $500 \mathrm{~K}$. wyb. ${ }^{7} \mathrm{~W}$ obliczu powyższego stanu rzeczy zasadne wydaje się włączenie do prowadzonych rozważań dorobku ukonstytuowanego na gruncie wskazanego czynu zabronionego. Przemawia za tym przede wszystkim treść użytych przez ustawodawcę wyrażeń („podawanie do wiadomości publicznej”, „,badania opinii publicznej”). Zgodnie z art. 85 URef.Ogól. „Kto w okresie od zakończenia kampanii referendalnej aż do zakończenia głosowania podaje do wiadomości publicznej wyniki badań (sondaży) opinii publicznej dotyczące przewidywanych zachowań głosujących w referendum i przewidywanych wyników referendum lub wyniki sondaży przeprowadzanych $\mathrm{w}$ dniu głosowania podlega grzywnie od 500000 do 1000000 złotych". Nieco inny kształt przybrał prawnokarny zakaz podawania do wiadomości publicznej wyników sondaży określony $\mathrm{w}$ art. 70 URef.Lok. Zgodnie z treścią tego przepisu: „Kto podaje do publicznej wiadomości wyniki badań opinii publicznej dotyczące przewidywanych zachowań mieszkańców w referendum i wyniku referendum oraz sondaży przeprowadzanych w dniu głosowania, z naruszeniem zakazu, o którym mowa w art. 32, podlega grzywnie". Normatywna konstrukcja znamion stypizowanego

względem form - z państw zachodnich przeniesiono liczne wzory propagandy wyborczej i okazało się, iż łatwo przyjmują się w społeczeństwie polskim. Obok wieców ożywianych występami popularnych artystów, plakatów, ulotek, pocztówek, folderów audycji telewizyjnych oraz radiowych, jeżdżących po ulicach specjalnych samochodów z urządzeniami nagłaśniającymi, płatnych reklam w prasie, indywidualnych listów do wyborców aż po video clipy".

6 Tak w odniesieniu do wyborów: S. Sagan, Polskie prawo konstytucyjne, Warszawa 2003, s. 107.

7 Szerzej na temat stypizowanego w tym przepisie występku zob. J. M. Wojciechowski, Przestępstwo podawania do wiadomości publicznej wyników sondaży w czasie obowiązywania ciszy wyborczej (art. 500 Kodeksu wyborczego), „Przegląd Sądowy” 2015, nr 6, s. 21-32. 
w tym przepisie występku ma charakter niekompletny i w przedmiocie rekonstrukcji odsyła do art. 32 URef.Lok. ${ }^{8}$ Dodatkowo, wskazany czyn zabroniony odmiennie niż występek określony w art. 85 URef.Ogól. obwarowany został karą grzywny w stawkach dziennych.

\section{Przedmiot ochrony}

Przechodząc do analizy ustawowych znamion występków stypizowanych w art. 85 URef.Ogól. oraz art. 70 URef.Lok. należy wskazać, że rodzajowym przedmiotem ochrony jest tutaj prawidłowy, zgodny z przepisami tych ustaw przebieg głosowania $\mathrm{w}$ referendum ogólnokrajowym oraz lokalnym ${ }^{9}$. Ustanowienie powyższych zakazów ma zabezpieczać prawidłową realizację przepisów materialnych zawartych we wskazanych aktach normatywnych (art. 41 URef.Ogól. oraz art. 32 URef.Lok.) ${ }^{10}$. Należy zwrócić uwagę na fakt, że w opisie znamion analizowanych występków mowa jest o ściśle określonej fazie procesu referendalnego - tzw. ciszy referendalnej, która oddziela okres kampanii od dnia głosowania trwając aż do momentu jego zakończenia. Pojęcie ciszy referendalnej, podobnie jak termin cisza wyborcza nie pojawia się w treści jakiegokolwiek powszechnie obowiązującego aktu prawnego ${ }^{11}$. Normatywną treść tej instytucji można

8 Zgodnie z treścią art. 32 URef.Lok: „Na 24 godziny przed dniem referendum aż do zakończenia głosowania zabrania się podawania do publicznej wiadomości wyników badań (sondaży) opinii publicznej dotyczących przewidywanych zachowań mieszkańców w referendum i wyników referendum oraz sondaży przeprowadzonych w dniu głosowania."

9 W. Kotowski, B. Kurzępa, Przestępstwa pozakodeksowe. Komentarz, Warszawa 2007, s. 634-635 i s. 648.

10 M. Jachimowicz, Przestępstwa z ustawy o referendum ogólnokrajowym, „Przegląd Sejmowy” 2008, nr 1(84), s. 70; M. Jachimowicz, Odpowiedzialność karna za naruszenie przepisów ustawy o referendum lokalnym, „Samorząd Terytorialny” 2006, nr 4, s. 44. Zdaniem Autora przedmiotem ochrony tych przepisów jest porządek w zakresie przeprowadzania referendum odpowiednio - ogólnokrajowego i lokalnego.

11 A. Sokala, B. Michalak, P. Uziębło, Leksykon prawa wyborczego i referendalnego oraz systemów wyborczych, Warszawa 2013, s. 28. „Cisza referendalna - to czas poprzedzający głosowanie, w którym zakazane jest prowadzeniem kampanii refe- 
odtworzyć poddając analizie poszczególne przepisy ustaw referendalnych oraz Kodeksu wyborczego. Zakaz podawania do wiadomości publicznej wyników badań (sondaży) opinii publicznej jest obok zakazu agitacji jednym z dwóch istotnych elementów, które determinują normatywny kształt tej instytucji ${ }^{12}$. Cisza referendalna, podobnie jak cisza wyborcza ma złożoną konstrukcję, a regulacje jakie obowiązują w krajach w których występuje ta instytucja różnią się w przedmiocie zakresu miejscowego i czasowego oraz katalogu zachowań zabronionych $\mathrm{w}$ czasie jej obowiązywania ${ }^{13}$. Indywidualnym przedmiotem ochrony art. 85 URef.Ogól. oraz art. 70 URef.Lok. jest swoboda głosowania w referendum. Ustanowienie ciszy referendalnej „(..) ma na celu stworzenie osobom głosującym warunków do spokojnego zapoznania się z argumentami i konsekwencjami wyboru określonej opcji, zniwelowania znanego w psychologii społecznej „efektu świeżości” (polegającego na lepszym zapamiętywaniu i przyswajaniu informacji prezentowanych pod koniec procesu komunikacyjnego) oraz stwo-

rendalnej w jakiejkolwiek formie. Jej występowanie ma zapewnić uprawnionym do głosowania czas na refleksję i podjęcie decyzji w sposób wolny od wpływów zewnętrznych, w szczególności wiążących się z działaniem marketingu politycznego. (...) W Polsce zarówno w odniesieniu do referendum ogólnokrajowego jak i lokalnego (podobnie jak w przypadku ciszy wyborczej), zaczyna się ona na 24 godziny przed dniem głosowania i trwa aż do czasu zakończenia głosowania. W tym czasie zakazane jest zwoływanie zgromadzeń, organizowanie pochodów i manifestacji, wygłaszanie przemówień, rozdawanie ulotek, jak również prowadzenie kampanii referendalnej w jakikolwiek inny sposób. (...) Cisza referendalna obejmuje również zakaz publikacji w tym czasie wyników badań opinii publicznej dotyczących przewidywanych zachowań głosujących w referendum. Dotyczy to zarówno sondaży przeprowadzonych w dniach poprzedzających głosowanie, jak i w dniu lub dniach takiego głosowania".

12 Tak w odniesieniu do wyborów przed uchwaleniem Kodeksu wyborczego z 5 stycznia 2011 roku: A. Frydrych, B. Michalak, M. Sobczyk, Zagadnienia prawnej regulacji ciszy wyborczej i dopuszczalności prowadzenia w okresie ciszy wyborczej kampanii społecznej na rzecz podwyższenia partycypacji wyborczej, [w:] J. Zbieranek (red.), Prawo wyborcze Analizy. Interpretacje. Rekomendacje, Warszawa 2009, s. $19-20$.

13 Szerzej na temat ciszy wyborczej zob. M. M. Wiszowaty, Instytucja ciszy wyborczej. Geneza, regulacja prawna, ratio existendi, „Studia Wyborcze” 2012, tom XIV, s. 8-10. 
rzenie warunków do przemyślenia i podjęcia decyzji w warunkach wolnych od perswazyjnego i intensywnego charakteru kampanii"14. Wynik głosowania w referendum, podobnie, jak w przypadku wyborów ${ }^{15}$ może bowiem zostać zdeformowany na skutek takich zjawisk, jak m.in. „efekt śnieżnej kuli (ang. bandwagon effect)”, 16 , „przepływ ostatniej chwili (ang. last minute swing)”17, „,spirala milczenia (ang. spiral of silence)"18. Badania opinii publicznej nie zawsze będą rów-

14 A. Frydrych, B. Michalak, O problemie dopuszczalności prowadzenia kampanii profrekwencyjnej w okresie ciszy referendalnej, „Przegląd Sejmowy” 2012, nr 1, s. 47.

15 Zob. J. M. Wojciechowski, Przestępstwo podawania do wiadomości..., s. $24-25$.

16 Tak w odniesieniu do wyborów: B. Michalak, A. Sokala, P. Uziębło, Leksykon prawa wyborczego i referendalnego..., s. 49. „Efekt śnieżnej kuli (bandwagon effect) zjawisko to polega na stopniowym, ale konsekwentnym i stale powiększającym się przenoszeniu głosów wyborców (najczęściej niezdecydowanych) na partie/kandydatów, które prowadzą w sondażach przedwyborczych. W ten sposób przewidywany zwycięzca zyskuje dodatkowe głosy tylko z tego powodu, że jest na czele stawki, co jeszcze bardziej zwiększa prawdopodobieństwo jego wygranej i w ten sposób przyciąga kolejne głosy, tak jak tocząca się kula śnieżna, która im jest większa, tym więcej zbiera śniegu".

17 Tamże, s. 115. „Przepływ ostatniej chwili (last minute swing) - przepływ ostatniej chwili, wyborcy ostatniej chwili, spóźnienie konformiści lub tzw. niezdecydowani do końca. Pojęcie można określić również nagłe podjęcie decyzji o oddaniu głosu przez osoby do tej pory niezdecydowane lub wcześniej w ogóle nie zamierzające uczestniczyć w głosowaniu. Cechą opisanych zachowań jest to, że mają one miejsce bezpośrednio przed terminem wyborów, w ostatnich dniach, czasami nawet godzinach, kampanii wyborczej. Motywem takiego postępowania mogą być wyniki ostatnich sondaży wyborczych publikowanych przed dniem wyborów lub tzw. ciszą wyborczą. Część wyborców, zamiast własną opinią, kieruje się wynikami sondaży (koniecznie chcą być po stronie zwycięzców lub przeciwnie - wolą zagłosować na partię, której notowania zaczynają spadać). Efekt „last minute swing" zauważany jest post factum, już po przeprowadzonych wyborach, kiedy okazuje się, że ich wyniki różnią się istotnie od wcześniejszych prognoz".

18 Tamże, s. 218-219 „Spirala milczenia (spiral of silence) - zjawisko polegająca na wycofywaniu się ludzi z publicznego wyrażania własnych opinii w sprawach społeczno-politycznych w sytuacji, w której w społeczeństwie dominuje (albo ludziom tak się wydaje) pogląd przeciwny. W ten sposób ludzie o innych poglądach "milkną". Przestają się wypowiadać publicznie i nie odpowiadają szczerze na pytania ankieterów, przez co wyniki badań opinii publicznej mogą nie do końca pokrywać się z faktycznym rozkładem w społeczeństwie opinii na dany temat. Teoria spirali milczenia zakłada, że całe społeczeństwo (a nie tylko grupy, w których funkcjonuje jednostka) grozi izolacją i odrzuceniem tym jednostkom, które sprzeciwiają się porozumieniu. Z kolei jednostki mają zakorzenioną, najczęściej nie- 
nież wiarygodnym źródłem rozkładającego się wśród wyborców poparcia, z uwagi na wpływ takich zjawisk, jak m. in. „overclaming”19, efekty: „ankietera (ang. interviewer error)”20, „badacza (ang. experimenter error, observer bias)", ${ }^{21}$ wywiadu (ang. interview bias) ${ }^{22}$, czy „efekt potakiwania (zgody respondenta; ang. acquiescence bas)”23. Uzyskanie możliwie najbardziej wiarygodnego wyniku głosowania odzwierciedlającego rzeczywiste poglądy i preferencje osób biorących w nim czynny udział ma istotne znaczenie z perspektywy roli, jaką w polskim porządku prawnym odgrywa referendum. W świetle

świadomą obawę przed izolacją. Ta obawa skłania je do ciągłego upewniania się, jakie opinie i zachowania są $\mathrm{w}$ danym momencie aprobowane albo potępiane społecznie, które postawy ulegają nasileniu, a które słabnięciu".

19 Zob. http://dobrebadania.pl/slownik-badawczy.html, (dostęp: 12.03.2016r.) „Overclaimining - określenie zachowania części respondentów biorących udział w badaniach opinii, polegającego na udzielaniu przez nich nieprawdziwych odpowiedzi na temat własnych przekonań, poglądów politycznych, uczestnictwa w życiu społecznym, wyznawanych norm i wartości, statusu społecznego itp. Overclaiming jest szczególnie często spotykany w sondażach wyborczych dotyczących poparcia dla kandydatów lub partii startujących w wyborach. Część respondentów deklaruje wtedy poparcie dla określonego kandydata lub partii, chociaż wcale nie zamierzają brać udziału w głosowaniu lub w rzeczywistości popierają zupełnie innego kandydata".

20 Tamże „Efekt ankietera (ang. interviewer error) zafałszowanie odpowiedzi udzielanych przez respondenta, spowodowane jego reakcją na sposób zachowania lub wygląd ankietera. Czasami zafałszowanie takie powstaje również w wyniku błędnych przeświadczeń respondenta na temat oczekiwań ankietera wobec jego osoby.

21 Tamże. „Efekt badacza (ang. experimenter terror, observer bias) zafałszowanie wyników badania, eksperymentu lub obserwacji spowodowane niewłaściwym zachowaniem badacza wobec badanej osoby (wywieraniem presji, sugerowaniem oczekiwanego zachowania)".

22 Tamże. „Efekt wywiadu (ang. interview bias) - błąd popełniany w trakcie wywiadu przez ankietera, respondenta lub obie osoby jednocześnie. Najczęściej polega to na tym, że ankieter sugeruje respondentowi odpowiedzi, które powinien mu udzielić lub odwrotnie - respondent z własnej inicjatywy odpowiada w taki sposób, żeby spełnić oczekiwania ankietera, zrobić na nim korzystne wrażenie itp.".

23 Tamże. „Efekt zgody respondenta; ang. acquiescence bas) - zafałszowanie wyników badania spowodowane tym, że respondent $\mathrm{w}$ trakcie wywiadu udziela pozytywnych odpowiedzi na wszystkie lub większość pytań zamieszczonych w kwestionariuszu. Efekt potakiwania może być spowodowany: 1.przekonaniem respondenta, że takich właśnie odpowiedzi oczekuje ankieter. 2.sugerowaniem pozytywnych odpowiedzi przez samego ankietera. 3. znudzeniem lub zmęczeniem respondenta i chęcią jak najszybszego zakończenia wywiadu". 
art. 4 ust. 2 Konstytucji RP instytucja ta należy do głównych narzędzi bezpośredniego sprawowania władzy państwowej przez Naród, rozumiany jako ogół obywateli RP, z kolei na gruncie na art. 170 Konstytucji RP referendum jest instrumentem prawnym, który pozwala decydować członkom wspólnoty samorządowej o kluczowych sprawach związanych z jej funkcjonowaniem.

\section{Strona przedmiotowa}

Występki, o których mowa w art. 85 URef.Ogól. oraz w art. 70 URef.Lok. można popełnić tylko w czasie od zakończenia kampanii referendalnej aż do zakończenia głosowania (tj. w okresie obowiązywania tzw. ciszy referendalnej). Dyspozycje wskazanych przepisów nie są kompletne i w sposób ukryty odsyłają do treści innych przepisów prawa referendalnego, a także wyborczego ${ }^{24}$. Wśród tych regulacji znajduje się art. 38 URef.Ogól. oraz art. 29 ust. 1 URef.Lok., które określają moment zakończenia kampanii i rozpoczęcia ciszy referendalnej. Zgodnie z treścią wymienionych przepisów kampania rozpoczyna się z dniem ogłoszenia uchwały Sejmu, postanowienia Prezydenta Rzeczypospolitej lub postanowienia Marszałka Sejmu o zarządzeniu referendum ogólnokrajowego, bądź podjęcia uchwały organu stanowiącego jednostki samorządu terytorialnego czy postanowienia komisarza wyborczego o przeprowadzeniu referendum lokalnego, a ulega zakończeniu na 24 godziny przed dniem głosowania. Wtedy to rozpoczyna się cisza referendalna, która trwa aż do momentu zakończenia głosowania. Przepisy określające czas zakończenia głosowania, który jest drugą ramą temporalną, o której mowa w znamionach wskazanych występków nie zostały jednak ukształtowane w sposób sztywny. Głosowanie w referendum ogólnokrajowym trwa od godziny $6^{00}$ do $22^{00}$ (art. 5 ust. 3 URef.Ogól.) jednak w praktyce może one zo-

24 Zob. J. M. Wojciechowski, Przestępstwo podawania do wiadomości..., s. 26. 
stać przedłużone bądź odroczone do dnia następnego ${ }^{25} \mathrm{w}$ przypadku zaistnienia nadzwyczajnych wydarzeń przejściowo uniemożliwiających głosowanie ${ }^{26}$. Tego rodzaju możliwość stwarza art. $47 \mathrm{~K}$. wyb., do którego stosowania odsyła art. 5 URef.Ogól. ${ }^{27}$ oraz art. 1 ust. 2 URef.Lok. ${ }^{28}$.

Wskazane występki w praktyce mogą zostać popełnione zarówno przy wykorzystaniu środków masowego komunikowania (m.in. Internetu, radia, prasy, telewizji), jak też na skutek czynności przedsiębranych osobiście przez sprawcę (np. ogłoszenie wyników sondaży przed lokalem wyborczym, w miejscach kultu religijnego, itp.)29. Nie ulega wątpliwości, że druga z przedstawionych form w praktyce bę-

25 Tak w odniesieniu do wyborów: B. Banaszak, Kodeks Wyborczy. Komentarz, Warszawa 2014, s. 96.

26 Art. $47 \S 1 \mathrm{~K}$. Wyb. „Głosowania nie wolno przerywać. Gdyby wskutek nadzwyczajnych wydarzeń głosowanie było przejściowo uniemożliwione, obwodowa komisja wyborcza może zarządzić jego przerwanie, przedłużenie albo odroczenie do dnia następnego. Uchwałę $\mathrm{w}$ sprawie przedłużenia albo odroczenia do dnia następnego głosowania obwodowa komisja wyborcza podejmuje po uzyskaniu zgody właściwej komisji wyborczej wyższego stopnia. Uchwała w tej sprawie powinna być natychmiast podana do publicznej wiadomości, przekazana właściwej komisji wyborczej wyższego stopnia, wójtowi oraz przesłana Państwowej Komisji Wyborczej za pośrednictwem komisji wyborczej wyższego stopnia."

27 Art. 5 ust. 1. Głosować można tylko osobiście. Ust. 2. Głosowanie odbywa się w lokalu obwodowej komisji do spraw referendum, w ciągu jednego dnia lub dwu kolejnych dni.

3. Jeżeli głosowanie $w$ referendum przeprowadza się w ciągu jednego dnia, głosowanie odbywa się bez przerwy od godziny $6^{00}$ do $22^{00}$.

4. Jeżeli głosowanie w referendum przeprowadza się w ciągu dwóch dni, głosowanie odbywa się każdego z tych dni bez przerwy od godziny $6^{00}$ do $20^{00}$, a przerwa następuje od godziny $20^{00}$ pierwszego dnia do godziny $6^{00}$ drugiego dnia.

5. Do trybu przeprowadzenia głosowania stosuje się odpowiednio przepisy ustawy z dnia 5 stycznia 2011 r. - Kodeks wyborczy (Dz.U. Nr 21, poz. 112, z późn. zm.).

28 Art. 1 ustawy o referendum lokalnym:

1. Ustawa określa zasady i tryb przeprowadzania referendum lokalnego.

2. W zakresie nieuregulowanym $\mathrm{w}$ ustawie do referendum lokalnego stosuje się odpowiednio przepisy ustawy z dnia 5 stycznia 2011 r. - Kodeks wyborczy (Dz.U. Nr 21, poz. 112, z późn. zm.).

29 Zob. J. M. Wojciechowski, Przestępstwo podawania do wiadomości..., s. 26-27. 
dzie występować znacznie rzadziej, na co niewątpliwie wpływ ma popularność mediów oraz ich szerszy zakres oddziaływania.

Zachowanie sprawcze polegające na podaniu do wiadomości publicznej wyników sondaży będzie wiązać się z ich skierowaniem do nieograniczonego kręgu osób ${ }^{30}$. Biorąc pod uwagę brzmienie analizowanych regulacji oraz posiłkując się wynikami wykładni a contrario należy wskazać, że de lege lata nie będzie wyczerpywać znamion analizowanego przestępstwa podanie do wiadomości publicznej badań opinii publicznej (sondaży), których adresatem jest ściśle określony krąg osób (pracownicy urzędu gminy (miasta), członkowie komitetu referendalnego - J. W. ${ }^{31}$.

Podawane do wiadomości publicznej informacje mogą dotyczyć wyników badań opinii publicznej (sondaży), które były już wcześniej publikowane w środkach masowego komunikowania. Należy w tym miejscu zauważyć, że znamiona analizowanych występków wiążą odpowiedzialność karną z realizacją zachowania sprawczego w ściśle oznaczonym czasie, którym jest okres ciszy referendalnej. Kwestia tego, czy wskazane wyniki były już wcześniej publikowane może mieć co najwyżej wpływ na wymiar kary (art. 53 k.k.) przemawiając za zastosowaniem łagodniejszej sankcji32.

Nie będzie wyczerpywać znamion występków określonych w art. 85 URef.Ogól. i art. 70 URef.Lok. podanie do wiadomości publicznej wyników badań opinii publicznej (sondaży), które ma miejsce jeszcze w czasie trwania kampanii (np. 2 godziny przed jej zakończeniem) i wiąże się z zaniechaniem ich usunięcia przed rozpoczęciem ciszy referendalnej. Mimo, że tego rodzaju badania (sondaże) opinii pu-

30 Tak w odniesieniu do wyborów: S. J. Jaworski, [w:] Kodeks wyborczy, Komentarz, K. W. Czaplicki, B. Dauter, S. J. Jaworski, A. Kisielewicz, F. Rymarz, Warszawa 2014, s. 976.

31 Tak w odniesieniu do wyborów: M. Jachimowicz, Przestępstwa z ustawy - Kodeks Wyborczy, „Kwartalnik Krajowej Szkoły Sądownictwa i Prokuratury” 2012, nr 1 (3), s. 21; B. Dauter, [w:] Samorządowe prawo wyborcze. Komentarz, K. Czaplicki, B. Dauter, A. Kisielewicz, F. Rymarz, Warszawa 2010, s. 517; S. J. Jaworski, [w:] Kodeks wyborczy. Komentarz..., s. 976.

32 Zob. J. M. Wojciechowski, Przestępstwo podawania do wiadomości..., s. 27. 
blicznej są widoczne dla wyborców w czasie, o którym mowa w opisie znamion analizowanych czynów zabronionych, to należy jednocześnie mieć na uwadze fakt, że ich opublikowanie miało miejsce poza wskazanym okresem. W praktyce nie można wykluczyć sytuacji, gdy podawane do wiadomości publicznej wyniki badań opinii publicznej (sondaży) zostaną ukryte w treści innych informacji podawanych do wiadomości publicznej w czasie trwania ciszy referendalnej ${ }^{33}$.

Czynność sprawcza, o której mowa w znamionach analizowanych czynów zabronionych polega na podawaniu do wiadomości publicznej w okresie od zakończenia kampanii referendalnej do zakończenia głosowania określonych kategorii informacji. W przypadku referendum ogólnokrajowego są to wyniki badań (sondaży) opinii publicznej dotyczące przewidywanych zachowań głosujących w referendum i przewidywane wyniki referendum lub wyniki sondaży przeprowadzane w dniu głosowania. Natomiast na gruncie referendum lokalnego mowa jest o wynikach badań opinii publicznej dotyczących przewidywanych zachowań mieszkańców w referendum i wyników referendum oraz sondaży przeprowadzanych w dniu głosowania Podawanie do wiadomości publicznej informacji niewymienionych $\mathrm{w}$ dyspozycji analizowanych przepisów w okresie od zakończenia kampanii referendalnej do zakończenia głosowania nie będzie skutkować odpowiedzialnością karną po stronie osoby, która dopuszcza się tego rodzaju czynności ${ }^{34}$.

Pojęcie „zachowań głosujących w referendum”, o których mowa w znamionach występku z art. 85 URef.Ogól. należy rozumieć szeroko i postrzegać jako ogół relacji (stosunków) zachodzących pomiędzy

33 Tak w odniesieniu do wyborów: W. Peszyński, A. Seklecka, Rola sondaży w polskiej kampanii prezydenckiej w 2010, „Studia Wyborcze” 2010, t. 10, s. 42-43. Zob. również J. M. Wojciechowski, Przestępstwo podawania do wiadomości..., s. 27; http://socialpress.pl/2015/05/podwawelska-czy-mysliwska-internauci-awirtualna-cisza-wyborcza, (dostęp:12.03.2016). Warto zauważy, że tego rodzaju sytuacja miała miejsce w trakcie wyborów prezydenckich w 2015 roku. Wyniki sondaży wyborczych obrazujące rywalizację pomiędzy B. Komorowskim a A. Dudą podawane były pod postacią potraw i produktów spożywczych.

34 Zob. J. M. Wojciechowski, Przestępstwo podawania do wiadomości..., s. 27-28. 
osobami uprawnionymi do głosowania, a procesem referendalnym. Jakkolwiek ustawodawca użył tutaj sformułowania „badania (sondaże opinii publicznej)", to jednak nie sposób nie zauważyć, że chodzi tutaj o wszelkie informacje dotyczące głosowania, niezależnie od ich nazwy ${ }^{35}$. Pojęcie to może obejmować wyrażanie preferencji, absencję, zainteresowanie referendum, udział w kampanii, itp. ${ }^{36}$. Zachowania referendalne każdego społeczeństwa, podobnie jak zachowania wyborcze mogą być poddawane prawomocnej analizie na różnych jego płaszczyznach. W zakresie analizowanego pojęcia będą się mieścić przede wszystkim informacje związane ze sposobem głosowania, frekwencją, głosami nieważnymi, czy też elementami dotyczącymi preferencji (ze względu na płeć, wiek, wykształcenie, przynależność do grupy społeczno - zawodowej) ${ }^{37}$. Na tym tle należy zwrócić uwagę na różnice zachodzące pomiędzy znamionami czynu zabronionego z art. 85 URef.Ogól., a występku określonego w art. 70 URef.Lok., gdzie ustawodawca posłużył się terminem „zachowań mieszkańców w referendum” zamiast „zachowań osób głosujących”. Nie ulega wątpliwości, że pierwsze ze wskazanych pojęć ma szerszy zakres znaczeniowy, gdyż poza osobami biorącymi udział w głosowaniu dotyczy również osób nieposiadających prawa do głosowania oraz niebiorących (z różnych powodów) udziału w głosowaniu. Występujące w znamionach pojęcie „zachowania mieszkańców w referendum” nadaje wskazanemu uregulowaniu niezwykle restrykcyjny wymiar, gdyż w przyjętym brzmieniu przepis ten może być stosowany względem wszelkich zachowań, które wykazują choćby niewielki związek z głosowaniem w referendum lokalnym. W kontekście obu analizowanych czynów zabronionych kluczową rolę będzie odgrywać frekwencja, która w przypadku referendum lokalnego jest warunkiem sine qua non jego ważności, natomiast w odniesieniu do referendum ogólnokrajowego

35 P. Uziębło, Ustawa o referendum lokalnym. Komentarz, Warszawa 2008, s. 127.

36 Zob. J.M. Wojciechowski, Przestępstwo podawania do wiadomości..., s. 28-29; J. Raciborski, Polskie wybory. Zachowania..., s. 11.

37 Tak w odniesieniu do wyborów: J. Raciborski, Polskie wybory. Zachowania..., s. 145. 
decyduje o wiążącym wyniku zapadłego w głosowaniu rozstrzygnięcia. Na tym tle kontrowersje może wzbudzać kwestia podawania do wiadomości publicznej w czasie trwania głosowania komunikatów Państwowej Komisji Wyborczej dotyczących rzeczywistej liczby kart do głosowania wydanych przez organy wyborcze. Zdaniem Państwowej Komisji Wyborczej podawanie tego rodzaju wiadomości w czasie głosowania nie jest naruszeniem ciszy referendalnej, gdyż frekwencję $\mathrm{w}$ referendum ustala się na podstawie kart wyjętych z urny, a nie wydanych przez organy wyborcze ${ }^{38}$. Z przedstawionym stanowiskiem nie zgadza się P. Uziębło, który słusznie wskazuje, że de lege lata brak jest oparcia normatywnego dla wyłączania tego typu komunikatów Państwowej Komisji Wyborczej spod zakresu obowiązywania analizowanych zakazów ${ }^{39}$. Autor ten trafnie wywodzi, że tego rodzaju informacje mają związek z frekwencją i nie pozostają bez wpływu na wynik rozstrzygnięcia zapadłego $\mathrm{w}$ referendum ${ }^{40}$.

Kolejny typ zachowania sprawczego, o którym mowa w znamionach czynów zabronionych z art. 85 URef.Ogól oraz z art. 70 URef.Lok. polega na podawaniu do wiadomości publicznej w czasie od zakończenia kampanii referendalnej do zakończenia głosowania wyników sondaży przeprowadzanych $\mathrm{w}$ dniu głosowania. Powyższe uregulowanie dotyczy szczególnej kategorii badań opinii publicznej - tj. sondaży exit-polls, które są stałym i nieprzerwanym elementem niemal wszystkich wyborów i referendów w realiach ustrojowych III Rzeczpospolitej. Tego typu badania przeprowadzają $\mathrm{w}$ dniu głosowania z osobami opuszczającymi lokale wyborcze ankieterzy, którzy za pomocą opracowanego wcześniej wzoru wybierają osoby uprawnione

38 Zob. Uchwała Państwowej Komisji Wyborczej z dnia 26 maja 2003 roku w sprawie wytycznych dla obwodowych komisji do spraw referendum i dla komisarzy wyborczych w sprawie przekazywania Państwowej Komisji Wyborczej informacji o liczbie osób uprawnionych do głosowania oraz liczbie wydanych kart do głosowania w pierwszym dniu głosowania w referendum ogólnokrajowym zarządzonym na dzień 8 czerwca 2003 roku za: P. Uziębło, Ustawa o referendum lokalnym. Komentarz, Warszawa 2008, s. 127.

39 P. Uziębło, Ustawa o referendum lokalnym. Komentarz, Warszawa 2008, s. 127.

40 Tamże. 
do głosowania zadają im pytania pozwalające określić ich profil społeczno-demograficzny oraz proszą o wypełnienie krótkiej ankiety, w której znajdują się pytania dotyczące sposobu głosowania w referendum. Na podstawie tych badań podaje się pierwsze, przybliżone wyniki głosowania tuż po jego zakończeniu ${ }^{41}$.

Oba analizowane występki mają charakter formalny, gdyż w opisie ich znamion nie mieści się wywołanie jakichkolwiek skutków ${ }^{42}$. Wskazane czyny zabronione mogą zostać popełnione wyłącznie przez działanie. Jako prawnokarnie irrelewantne należy postrzegać czynności przygotowawcze poprzedzające podanie do publicznej wiadomości wyników badań opinii publicznej (sondaży), nawet jeżeli tego rodzaju czynności są przedsiębrane w czasie trwania ciszy referendalnej. Do takich wniosków prowadzi wykładnia literalna art. $16 \S 2$ k.k. oraz normatywna konstrukcja występków stypizowanych w art. 85 URef.Ogól. oraz art. 70 URef.Lok., które wiążą odpowiedzialność karną wyłącznie $\mathrm{z}$ podaniem do wiadomości publicznej wyników badań (sondaży) opinii publicznej dotyczących przewidywanych zachowań głosujących (mieszkańców) w referendum i przewidywanych wyników referendum lub wyników sondaży przeprowadzanych $\mathrm{w}$ dniu głosowania w okresie ciszy referendalnej. W obliczu obowiązującego stanu prawnego takie czynności, jak przeprowadzanie badań ankietowych wśród głosujących, ich opracowywanie, czy też druk materiałów zawierających wyniki sondaży referendalnych nie będą skutkować odpowiedzialnością karną za wskazane występki³.

41 Zob. J.M. Wojciechowski, Przestępstwo podawania do wiadomości..., s. 29; W. Peszyński, A. Seklecka, Rola sondaży w polskiej...., s. 29-30.

42 M. Jachimowicz, Przestępstwa z ustawy o referendum..., s. 71; M. Jachimowicz, Odpowiedzialność karna za naruszenie..., s. 45; M. Jachimowicz, Przestępstwa z ustawy Kodeks wyborczy..., s. 22; M. Bojarski, [w:] M. Bojarski (red.), System prawa karnego, tom 11, Szczególne dziedziny prawa karnego. Prawo karne wojskowe, skarbowe i pozakodeksowe, Warszawa 2014, s. 971; J.M. Wojciechowski, Przestępstwo podawania do wiadomości..., s. 29.

43 Zob. J.M. Wojciechowski, Przestępstwo podawania do wiadomości..., s. 29. 


\section{Podmiot przestępstwa}

Występki określone w art. 85 URef.Ogól. i w art. 70 URef.Lok. mają charakter powszechny. Świadczy o tym występujący w ich znamionach zaimek „kto” wskazujący na bliżej niesprecyzowany krąg adresató ${ }^{44}$. W praktyce sprawcą tych czynów może więc być każda osoba zdolna do ponoszenia odpowiedzialności karnej na podstawie przepisów Kodeksu karnego z 6 czerwca 1997 roku5. Ograniczony dostęp do badań exit-polls przesądza o tym, że sprawcami występków podawania do wiadomości publicznej tych kategorii sondaży będą przede wszystkim przedstawiciele środków masowego komunikowania46 oraz osoby, które z ich ramienia zlecają przeprowadzanie tego rodzaju badań. W przypadku materiału prasowego podmiotem odpowiedzialnym za popełnienie przestępstwa będzie jego autor, którym najczęściej bywa dziennikarz. Z uwagi na fakt, iż odpowiedzialność ta nie została w szczególny sposób ukształtowana zastosowanie znajdą tutaj przepisy Kodeksu karnego z 1997 roku. Odmiennie przedstawia się natomiast kwestia odpowiedzialności karnej redaktora naczelnego, który zgodnie z art. 25 ust. 4 Prawa prasowego ${ }^{47}$ odpowiada za treść materiałów prasowych przygotowywanych przez redakcję ${ }^{48}$. Nie da się ukryć, że w przeważającej większości przypadków, to właśnie ten podmiot będzie podejmował decyzję o podaniu do wiadomości publicznej wyników sondaży referendalnych ${ }^{49}$.

44 M. Jachimowicz, Przestępstwa z ustawy o referendum..., s. 71; M. Jachimowicz, Odpowiedzialność karna za naruszenie..., s. 45; J.M. Wojciechowski, Przestępstwo podawania do wiadomości..., s. 29 - 30.

45 Ustawa z dnia 6 czerwca 1997 roku Kodeks karny (Dz. U. z 1997 r., nr 88, poz. 553 ze zm.).

46 B. Dauter, [w:] Ustawa o referendum lokalnym. Komentarz, K.W. Czaplicki, B. Dauter, A. Kisielewicz, F. Rymarz, Warszawa 2007, s. 253.

47 Ustawa z dnia 26 stycznia 1984 roku Prawo prasowe (Dz.U. z 1984, nr 5, poz. 24 ze zm.).

48 E. Czarny Drożdżejko, [w:] J. Barta, R. Markiewicz, A. Matlak (red.), Prawo mediów, Warszawa 2008, s. 723.

49 Tamże; Zob. również: J.M. Wojciechowski, Przestępstwo podawania do wiadomości..., s. 30. 


\section{Strona podmiotowa}

Oba analizowane czyny zabronione mają charakter umyślny 50 i mogą zostać popełnione zarówno w zamiarze bezpośrednim, jak i ewentualnym (ściślej quasi ewentualnym). Druga z wymienionych postaci umyślności będzie wchodzić w grę w przypadku, gdy sprawca podaje do wiadomości publicznej wyniki badań (sondaży) opinii publicznej bądź wyniki sondaży przeprowadzone $\mathrm{w}$ dniu głosowania nie mając przy tym pewności, czy głosowanie jeszcze trwa, czy też zostało przedłużone na podstawie uchwały Państwowej Komisji Wyborczej (art. 47 K. wyb. ${ }^{51}$. Podając do wiadomości publicznej wyniki tych badań osoba ta godzi się jednak z tym, że jej zachowanie może mieć miejsce w trakcie głosowania. Brak pewności, co do wystąpienia tego znamienia przemawia za możliwością popełnienia wskazanych czynów zabronionych $\mathrm{w}$ formie zamiaru quasi ewentualnego. W praktyce sprawcy analizowanych występków mogą działać z różnych motywów np. w celu osiągnięcia korzyści majątkowej, wyrażenia lekceważenia wobec obowiązującego porządku prawnego, zyskania popularności, wprowadzenia w błąd, etc. Przedstawione okoliczności, jakkolwiek nie występują w opisie znamion analizowanych występków, to jednak powinny zostać uwzględnione przez sąd na etapie wymiaru kary (art. 53 k.k.) $)^{52}$.

50 B. Dauter, [w:] Ustawa o referendum lokalnym. Komentarz, K.W. Czaplicki, B. Dauter, A. Kisielewicz, F. Rymarz, Warszawa 2007, s. 253; M. Jachimowicz, Przestępstwa z ustawy o referendum..., s. 71; M. Jachimowicz, Odpowiedzialność karna za naruszenie...., s. 45. W odniesieniu do wyborów zob. J.M. Wojciechowski, Przestępstwo podawania do wiadomości..., s. 30.

51 Zob. J.M. Wojciechowski, Przestępstwo podawania do wiadomości..., s. 30.

52 Tamże. 


\section{Wymiar kary}

Naruszenie zakazu określonego w art. 85 URef.Ogól. zagrożone zostało karą grzywny od 500000 zł do 1000000 zł. Grzywna ta ma charakter kwotowy tj. zarówno jej górna, jak i dolna granica zostały wyrażone w postaci konkretnej kwoty pieniężnej. Biorąc pod uwagę jej wysokość, należy wskazać, że jest to de lege lata jedna z najwyższych kar tego rodzaju grożąca za przestępstwo powszechne ${ }^{53}$. W zakresie jej orzekania zastosowanie znajdzie art. 11 § 3 Ustawy $\mathrm{z}$ dnia 6 czerwca 1997 roku przepisy wprowadzające Kodeks karny54: „Grzywnę, którą ustawa szczególna określa kwotowo, wymierza się z uwzględnieniem dochodów sprawcy, jego warunków osobistych, rodzinnych, stosunków majątkowych i możliwości zarobkowych." Okoliczność, iż zasady wymiaru grzywny zostały w sposób szczegółowy określone w przepisach wprowadzających Kodeks karny nie oznacza, że nie znajdą tutaj zastosowania dyrektywy wymiaru kary określone w art. 53 k.k. 55 . Na tym tle odmiennie przedstawia się sytuacja dotycząca występku określonego w art. 70 URef.Lok., który został obwarowany grzywną w stawkach dziennych. Jej wysokość kształtuje się na poziomie od 10 do 540 stawek dziennych (wysokość jednej stawki w świetle art. $33 \S 3$ k.k. nie może być niższa od 10 złotych, ani też przekraczać 2000 złotych). Dostrzegalne na tej płaszczyźnie rozbieżności wyrażające się w ustanawianiu różnych sankcji karnych za podobnego rodzaju zachowania nie wystawiają najlepszego świadectwa polityce legislacyjnej prowadzonej przez polskiego ustawodawcę. Dodatkowo, określona w art. 85 URef.Ogól. grzywna (od 500000 zł do 1000000 zł.) grożąca za przestępstwo powszechne rodzi poważne wątpliwości, w zakresie zgodności powyższego uregulowania z prze-

\footnotetext{
Tamże, s. 30 - 31.

Ustawa z dnia 6 czerwca 1997 roku Przepisy wprowadzające kodeks karny (Dz.U. z 2010, nr 98, poz. 626 ze zm.).

55 A. Marek, Kodeks karny. Komentarz, Warszawa 2010, s. 740.
} 
pisami Konstytucji RP (zwłaszcza art. 31 ust. 3 statuującym zasadę proporcjonalności) ${ }^{56}$.

\section{Zbieg przestępstw i zbieg przepisów}

Przywołane przepisy będą mogły pozostawać w zbiegu realnym $\mathrm{z}$ art. $191 \S 1 \mathrm{k} . \mathrm{k} . \mathrm{w}$ sytuacji, gdy sprawca zmuszając do wzięcia udziału w badaniach opinii publicznej (np. przed wejściem do lokalu wyborczego) zastosuje przemoc wobec osoby lub groźbę bezprawną. W praktyce nie można również wykluczyć zbiegu kumulatywnego art. 85 URef.Ogól. czy art. 70 URef.Lok z art. 250 k.k., art. 250a § 2 k.k., art. 251 k.k. Będzie on możliwy w zakresie, w jakim ujęte w znamionach przywołanych przestępstw zachowania będą poprzedzać realizację zachowań sprawczych, o których mowa w art. 85 URef.Ogól. lub art. 70 URef.Lok. stanowiąc dla sprawcy środek do pozyskiwania informacji o sposobie głosowania przez osoby uprawnione ${ }^{57}$. Analizowane przepisy mogą również pozostawać $\mathrm{w}$ zbiegu z regulacjami zakazującymi prowadzenia agitacji w okresie ciszy referendalnej. W przypad$\mathrm{ku}$, gdy sprawca podając do wiadomości publicznej wyniki badań (sondaży) opinii publicznej, o których mowa w analizowanych przepisach będzie również nakłaniał lub zachęcał, do głosowania w określony sposób, to jego czyn poza art. 85 URef.Ogól. lub art. 70 URef.Lok. będzie również naruszać dyspozycję wykroczenia z art. 84 URef.Ogól. lub art. 69 URef.Lok. Podobnie należy rozstrzygać sytuację, gdy sprawca w okresie ciszy referendalnej zorganizuje spotkanie z osobami uprawnionymi do głosowania (przy założeniu, że nie będzie to wąsko zakreślony, zamknięty krąg osób - J. W), na którym zaprezen-

\footnotetext{
56 Zob. J.M. Wojciechowski, Przestępstwo podawania do wiadomości..., s. 30-31.

57 Tamże.
} 
tuje wyniki sondaży referendalnych ${ }^{58}$. W tym przypadku zastosowanie znajdzie art. 10 § 1 Kodeksu wykroczeń, zgodnie z którym „Jeżeli czyn będący wykroczeniem wyczerpuje zarazem znamiona przestępstwa, orzeka się za przestępstwo i za wykroczenie, z tym że jeżeli orzeczono za przestępstwo i za wykroczenie karę lub środek karny tego samego rodzaju, wykonuje się surowszą karę lub środek karny. W razie uprzedniego wykonania łagodniejszej kary lub środka karnego zalicza się je na poczet surowszych"59.

\section{Zakończenie}

Nie ulega wątpliwości, że prawnokarne zakazy podawania do wiadomości publicznej wyników sondaży będące kluczowym ogniwem instytucji ciszy referendalnej oraz wyborczej są jednymi z najbardziej kontrowersyjnych regulacji, jakie obecnie występują w polskim porządku prawnym. Nie może być zresztą inaczej, jeżeli weźmie się pod uwagę fakt, że w okresie obowiązywania ciszy referendalnej ograniczeniu ulegają tak kluczowe prawa i wolności obywatelskie, jak m.in. prawo do informacji, czy wolność wrażania poglądów oraz pozyskiwania i rozpowszechniania informacji. $W$ tym kontekście niezwykle ważne jest, aby model prawnokarnej ochrony skonstruowany został w sposób prawidłowy. Z tej perspektywy kontrowersje rodzi skrajnie różna ocena tego samego zachowania na gruncie obowiązujących ustaw referendalnych wyrażająca się w obwarowania występku $\mathrm{z}$ art. 85 URef.Ogól. jedną z najwyższych kar grzywny kwotowej, jaka de lege lata występuje w polskim prawie karnym, podczas gdy tożsame zachowanie penalizowane na gruncie ustawy o referendum lokalnym zagrożone zostało karą grzywny w stawkach dziennych. Przyjęty w art. 85 URef.Ogól. wymiar grzywny nie koresponduje bowiem

58 Tak w odniesieniu do wyborów: S.J. Jaworski, [w:] Kodeks wyborczy. Komentarz..., s. 977.

59 Zob. J.M. Wojciechowski, Przestępstwo podawania do wiadomości..., s. 31-32. 
z charakterem wskazanego przestępstwa. Jakkolwiek od samego momentu pojawienia się $\mathrm{w}$ polskim porządku prawnym omawiany występek miał charakter powszechny, to jednak w początkowym okresie jego obowiązywania ograniczone możliwości dostępu do wyników badań opinii (sondaży) publicznych oraz środków masowego komunikowania (w tym zwłaszcza Internetu,) przesądzały o tym, że w praktyce jego sprawcami mogły być osoby wywodzące się z wąsko zakreślonego kręgu podmiotów (redaktorzy naczelni gazet, przedstawiciele środków masowego komunikowania, pracownicy ośrodków badań opinii publicznej). Warto również zauważyć, że głównym motywem, który legł u podstaw ustanowienia kary grzywny w przyjętym wymiarze (od $500.000 \mathrm{zł}$ do $1 \mathrm{mln}$. zł) były występujące w praktyce rażące przypadki łamania przez przedstawicieli środków masowego komunikowania zakazu podawania do wiadomości publicznej wyników sondaży w przeddzień głosowania ${ }^{60}$. W obliczu błyskawicznego rozwoju nowoczesnych technologii wyraźnemu rozszerzeniu uległ krąg potencjalnych sprawców tego przestępstwa, jak również pojawiły się szersze możliwości dostępu do wyników sondaży. W tym względzie należałoby rozważyć możliwość modyfikacji tak ukształtowanej sankcji karnej bądź zmianę wskazanego przestępstwa z powszechnego na indywidualny (znajdujący zastosowanie w odniesieniu do np. przedstawicieli środków masowego komunikowania).

\section{Literatura:}

Banaszak B., Kodeks Wyborczy. Komentarz, Wyd. C.H. Beck, Warszawa 2014. Bojarski M. (red.), System prawa karnego, tom 11, Szczególne dziedziny prawa karnego. Prawo karne wojskowe, skarbowe i pozakodeksowe, Wyd. C.H. Beck, Warszawa 2014.

60 Tak w odniesieniu do wyborów: S. Gebethner: Wybory na Urzq̨d Prezydenta Rzeczypospolitej Polskiej, Komentarz do Ustawy o wyborze Prezydenta RP, Warszawa 2000, s. 213. 
Czaplicki K. W., Dauter B., Kisielewicz A., Rymarz F., Samorzqdowe prawo wyborcze. Komentarz, Wyd. Wolters Kluwer, Warszawa 2010.

Czaplicki K. W., Dauter B., Kisielewicz A., Rymarz F., Ustawa o referendum lokalnym. Komentarz, Wyd. Wolters Kluwer, Warszawa 2007.

Czaplicki K.W., Dauter B., Jaworski S. J., Kisielewicz A., Rymarz F., Kodeks wyborczy, Komentarz, Wyd. Wolters Kluwer, Warszawa 2014.

Czarny Drożdżejko E. [w:] Barta J., Markiewicz R., Matlak A. (red.), Prawo mediów, Wyd. Lexis Nexis, Warszawa 2008.

Frydrych A., Michalak B., O problemie dopuszczalności prowadzenia kampanii profrekwencyjnej w okresie cisz referendalnej, „Przegląd Sejmowy” 2012, nr 1, s. 43-57.

Frydrych A., Michalak B., Sobczyk M., Zagadnienia prawnej regulacji ciszy wyborczej i dopuszczalności prowadzenia w okresie ciszy wyborczej kampanii społecznej na rzecz podwyższenia partycypacji wyborczej, [w:] J. Zbieranek (red.), Prawo wyborcze Analizy. Interpretacje. Rekomendacje, Warszawa 2009, Wyd. Instytutu Spraw Publicznych, s. 118.

Jachimowicz M., Odpowiedzialność karna za naruszenie przepisów ustawy o referendum lokalnym, „Samorząd Terytorialny” 2006, nr 4, s. 41-47.

Jachimowicz M., Przestępstwa z ustawy - Kodeks Wyborczy, „Kwartalnik Krajowej Szkoły Sądownictwa i Prokuratury" 2012, nr 1 (3), s. 15-37.

Jachimowicz M., Przestępstwa $z$ ustawy o referendum ogólnokrajowym, „Przegląd Sejmowy” 2008, nr 1(84), s. 65-74.

Kotowski W., Kurzępa B., Przestępstwa pozakodeksowe, Komentarz, Wyd. LexisNexis 2007, Warszawa 2007.

Marek A., Kodeks karny. Komentarz, Wyd. Lexis Nexis, Warszawa 2010.

Peszyński W., Seklecka A., Rola sondaży w polskiej kampanii prezydenckiej w 2010, „Studia Wyborcze” 2010, t. 10, s. 27-46;

Raciborski J., Polskie wybory. Zachowania wyborcze społeczeństwa polskiego w latach 1989-1995, Wyd. Naukowe Scholar, Warszawa 1997.

Sagan S., Polskie prawo konstytucyjne, Wyd. Prawnicze LexisNexis, Warszawa 2003.

Sokala A., Michalak B., Uziębło P., Leksykon prawa wyborczego i referendalnego oraz systemów wyborczych, Wyd. Wolters Kluwer, Warszawa 2013.

Uziębło P., Ustawa o referendum lokalnym. Komentarz, Wyd. Wolters Kluwer, Warszawa 2008.

Wiszowaty M. M., Instytucja ciszy wyborczej. Geneza, regulacja prawna, ratio existendi, „Studia Wyborcze” 2012, tom XIV, s. 7-34. 
Wojciechowski J. M., Przestępstwo podawania do wiadomości publicznej wyników sondaży w czasie obowiq̨zywania ciszy wyborczej (art. 500 Kodeksu wyborczego), „Przegląd Sądowy” 2015, nr 6, s. 21-32 